\title{
National infrastructure, small towns and sustainable mobility - experiences from policy and strategy in two Swedish municipalities
}

Paul Fenton

Journal Article

\section{Tweet}

N.B.: When citing this work, cite the original article.

This is an electronic version of an article published in:

Paul Fenton , National infrastructure, small towns and sustainable mobility - experiences from policy and strategy in two Swedish municipalities, Journal of Environmental Planning and Management, 2016.pp.1-23.

Journal of Environmental Planning and Management is available online at informaworldTM:

http://dx.doi.org/10.1080/09640568.2016.1246998

Copyright: Taylor \& Francis (Routledge): STM, Behavioural Science and Public Health Titles http://www.routledge.com/

Postprint available at: Linköping University Electronic Press

http://urn.kb.se/resolve?urn=urn:nbn:se:liu:diva-132458

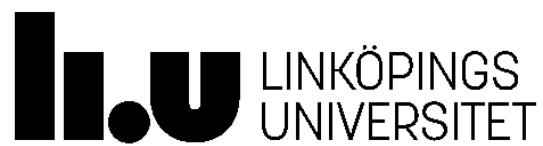


National infrastructure, small towns and sustainable mobility - experiences from policy and strategy in two Swedish municipalities

\section{Paul Fenton ${ }^{1}$}

${ }^{1}$ Corresponding author. Tel: +46 13 286602, Fax: +46 13 281101, Email: paul.fenton@liu.se, Division of Environmental Technology \& Management, Linköping University, 58183 Linköping, Sweden

Abstract

This study explores the implications of improved access to national rail and road infrastructure for urban planning and land use in two small Swedish towns. The promotion of sustainable mobility is considered a strategic objective at the municipal level, yet the study questions the extent to which national investments, and increased access to regional labour markets, support local efforts to increase sustainable mobility. The results indicate that municipalities struggle to adopt coherent approaches to increasing sustainable mobility and continue to develop physical plans that induce use of motor vehicles, a trend reinforced by national investments in road infrastructure in peri-urban areas.

Keywords Transport infrastructure; sustainable mobility; strategy, planning; municipalities; Sweden 


\section{Introduction}

Investments in national rail and road infrastructure are often claimed to be socio-economically beneficial, with improved infrastructure providing necessary pre-conditions for connected regions to develop, expand and take advantage of co-benefits (Knudsen and Rich, 2013; Lakshmanan, 2011; Cantos et al., 2005). However, increased provision of infrastructure has also been observed to induce demand, permitting and in some ways embedding and locking-in movements of persons or goods using transport modes that may generate negative environmental or social impacts, such as local air or noise pollution and greenhouse gas emissions (Mclntosh et al., 2014; World Bank, 2010).

Infrastructure investments - the manifestation of one form of strategy - may generate outcomes and impacts that conflict with other strategic objectives, be they local, regional or national (Banister and Berechman, 2001; Richardson, 2009). This paper focuses on the emergence of such conflicts at the local level, studying the influence of national rail and road infrastructure investments on two Swedish municipalities and their local strategic and physical planning. In particular, the paper aims to explore the extent to which the large-scale infrastructure investments enable, reinforce or support local objectives concerning sustainable mobility - or if these objectives are undermined, hindered or counteracted as a result of "socio-economically beneficial" infrastructure "improvements".

To do so, the paper presents results from a qualitative study, comprising document and interview studies, in order to explore the manifestation of sustainable mobility in strategic planning and its actualisation in physical planning. The extent to which sustainable mobility is present or absent from strategic and physical planning documents may indicate the presence of trade-offs or compromises which generate outcomes that negate the possibility to fulfil strategic objectives. This issue is explored in the discussion.

\section{Theoretical background}

\subsection{Transport planning and sustainable mobility}

In recent years, scientific literature on transport planning has increasingly understood that planning processes and decision-making are subjective and value-laden (Fenton and Gustafsson, 2015; Gao et al., 2013; Gudmundsson et al., 2016), whilst the behaviour of end-users is more haphazard than shown by the (typically quantitative) rationalist models underpinning the demand forecasts and socio-economic analyses that inform decision-making (Aditjandra, 2013; Banister, 2011; Rasouli and Timmermans, 2014; van Acker et al., 2013). Moreover, increasing awareness regarding the global environmental impacts of human activities has led to scrutiny of transportation's share of greenhouse gas emissions at the global, national and local levels (Hickman and Banister, 2014; Kenworthy, 2003; Schwanen et al., 2011). Similarly, local environmental and social challenges including noise pollution, accident rates or public health - have focused attention on negative impacts of mass automotive transportation (Dannenberg et al., 2003; Köhler et al., 2009; Woodcock et al., 2009).

Thus, there is increasing consensus that conventional means of transport planning have (a) induced demand for journeys, particularly by automobiles, and (b) downplayed the significance of 
transportation's negative impacts (European Union, 2011; Goldman and Gorham, 2006; UN-Habitat, 2012). A break from this path-dependency and a transition to sustainable mobility is thus a prerequisite - particularly in urban areas - to meet numerous critical challenges, not just to reduce the environmental impacts of transportation (in terms of both resources and impacts) but also to achieve other strategic objectives such as reduced congestion and increased accessibility (Banister, 2011; de Flander, 2015).

Municipal land use planning is considered "vital to shape transport behaviour" (Aditjandra, 2013: 78). In many countries (such as the EU Member States), sustainable mobility has been adopted as a concept in strategic and physical planning at the national, regional and local levels to promote and facilitate modal shift from resource-intensive transport - such as individual use of automobiles - to more sustainable forms of mobility (Lindenau and Böhler-Baedeker, 2014; Wefering et al., 2014). For example, some authors argue that planning should prioritise a spectrum of mobility options in terms of a hierarchy in which non-motorised forms of transport, such as walking and cycling, are ranked highest, with individual motorised transport ranked lowest (Bertolini and le Clerq, 2003).

However, a number of studies have identified barriers and challenges that impede or limit the implementation of sustainable mobility in practice. For example, Berger et al. (2014) name rebound effects, conflicting visions and lack of consensus, path dependencies and associated interests, and the diversity of user needs as significant challenges impeding a transition to sustainable mobility. Similar points are made by Hysing (2009), who suggests there is a need for new policy ideas, new administrative structures and the presence of engaged individuals if policy changes promoting sustainable mobility are to be institutionalised and succeed.

\subsection{Sustainable mobility in practice - the case of Sweden}

Swedish transport planning is conducted at multiple levels and the interplay between national, regional and local planning has important impacts on transport infrastructure. National agencies are responsible for planning and procuring investment in national road and rail infrastructure, whereas public transport is coordinated at the regional level, and local infrastructure (i.e. roads, cycle paths, pedestrian paths, etc.) is the responsibility of Sweden's 290 municipalities. Municipalities "host" national road and rail infrastructure, yet historically have had limited influence over its planning and introduction. At the same time, many municipalities attempt to use their strategic and physical planning to influence choice of transport modes in order to promote sustainable mobility (Antonson et al., 2016; Hrelja et al., 2015; Hysing et al., 2015).

Municipal self-government in Sweden has a long history. Municipalities are governed by elected representatives and have significant powers and responsibilities, including a monopoly on local physical planning (Lundqvist and von Borgstede, 2008; Nilsson et al., 2012; Wollman, 2008). The size (geographic area and population) of municipalities varies considerably, as does the extent to which they are able - or choose - to actively address all aspects of their portfolios. As such, municipalities have the opportunity to influence and shape transportation within their geographic zone (e.g. roads, speed limits, parking, etc.), but also are challenged by barriers including their physical size and the distances residents must travel, resources (as tax revenues are linked to population size), or the contours of local political debates. 
Planning tools - such as mobility management schemes - have been used in many contexts in an attempt to institutionalise and embed sustainable mobility in organisational practices (Hiselius and Rosqvist, 2016; Robertson, 2015). These typically emphasise an "order of priorities" concerning mobility options, in line with the hierarchy outlined in section 2.1. In addition, the "four-step principle" is used in Swedish transport infrastructure planning and advocates the following order of activities: (1) efforts to influence demand and mode, (2) efficient use of existing infrastructure, (3) limited reconstruction, before (4) major new construction is permitted (Nilsson et al., 2012). Thus, it may be expected that - when combined - the four-step principle and the principles of sustainable mobility should lead to a clear shift of emphasis in both strategic and physical planning.

Such a shift would (a) favour sustainable modes of transport and promote modal shift between modes; (b) influence the form of different modes (i.e. promote decarbonisation of vehicle fleets through technical innovation, etc.); (c) promote efficient use of current infrastructure for all forms of mobility (including those deemed less sustainable); and (d) limit the need for large-scale interventions, particularly those facilitating use of unsustainable modes of transport.

However, a number of studies have indicated that the integration of these concepts, and their deployment in planning processes, may have limited effects. For example, in a study of two Swedish municipalities, Karlstad and Sundsvall, Hrelja et al. (2015: 13) observe that "despite formal and informal tools that support a transition, there were several examples of how urban planning practices diverge from the goals of more climate-friendly transportation in both municipalities". For example, an "emphasis on 'attractive' housing that opens the way for settlements in peripheral locations, with inferior opportunities for public transportation, pedestrians and cycling" (Hrelja et al., 2015:14).

More generally, sustainable mobility becomes an important part of city branding, yet - as climate and transport are subordinated to wider economic interests - there is limited political will to enforce its conceptual content in planning processes (Hrelja et al., 2015:14). We may therefore expect to see evidence of compromises, trade-offs, conflicts and backlashes in municipalities that ostensibly claim to be promoting sustainable mobility (Hysing, 2009). In particular, we may expect to see a difference between the role and prominence of sustainable mobility in strategic planning and its manifestation in physical planning, resulting in incrementalism or counterproductive outcomes such as the proliferation of new road infrastructure or urban sprawl (Hrelja et al., 2015; Isaksson and Storbjörk, 2012).

In this paper, we explore the prominence of sustainable mobility in municipal strategic plans and physical plans in two small municipalities (with fewer than 50,000 residents). The paper studies urban planning in the context of a recently completed national infrastructure project that led to investments in both new and expanded railway infrastructure (linking three towns in the municipalities Motala and Mjölby), and an expanded and re-routed highway linking the two main towns of these municipalities and improving accessibility to the wider region.

Key questions include: how do the municipalities attempt to use strategic and physical planning to capitalise on the opportunities provided by new road and rail infrastructure? More pertinently, does this planning promote and improve conditions for sustainable mobility? And are there differences between the goals articulated in strategic plans and the implementation proposed in physical plans? 
In other words, the extent to which sustainable mobility is present or absent in municipal strategic and physical plans is explored, along with the implications of this presence and absence.

\section{Case selection}

This paper presents results from a study carried out within the framework of a wider Swedish national programme, "The Attractive Region". A brief introduction to this programme and the study is presented here, prior to a discussion of the methods used during the study.

\subsection{The Attractive Region}

The Attractive Region (DAR) is a three-year programme (2013-2016) focusing on the role of transportation in strategic planning. The programme aims to increase coordination and cooperation in planning processes in order to support regional development, environmentally efficient mobility and social sustainability. DAR is a multi-stakeholder initiative primarily comprising public sector organisations with a role in social planning, such as the Swedish Transport Administration, the Swedish National Board of Housing, Building and Planning, several regional administrations and the Swedish Association of Local Authorities and Regions. The programme is structured around six studies in so-called "pilot regions" and has a particular focus on small towns and communities and their integration in wider regions (Swedish Transport Administration, 2015).

One of the six pilot regions in DAR is "Västra Östergötland", a western sub-region of the County of Östergötland. Located in central Sweden, the County is comprised of 13 municipalities, the largest of which - Linköping and Norrköping - account for around two thirds of the County's approximately 440,000 residents. Around $77 \%$ of County residents live in settlements with more than 2,000 residents, yet only five towns have populations of over 10,000 residents and the "twin cities" of Linköping and Norrköping account for almost $45 \%$ of the County's urban population (SCB, 2014: 8687).

The County has a mixed economy, with most administrative, commercial, research and industrial activities located in or around the urban conurbations, and agriculture, forestry, mining and other activities in rural areas. Nationally significant highways and railways cross the County, primarily on a southwest-northeast axis (the E4 highway and southern mainline railway), and to a more limited extent on a northwest-southeast axis (see Figure 1). In sum, Östergötland is a county in transition, with increasing urbanisation and clustering in proximity to regional and national infrastructure.

$<<$ Insert Figure 1 here $>>$

In DAR, the pilot region "Västra Östergötland" is defined as a "regional triangle" comprising the central city of Linköping and its neighbouring municipalities of Mjölby (32 km to the west) and Motala (46 km to the northwest) (see Figure 1). The distance between the towns of Mjölby and Motala is $27 \mathrm{~km}$. This sub-region was subject to major infrastructure investments, in the form of improved road and rail capacity and the extension of commuter rail traffic to Motala (Swedish Transport Administration, 2015). This project, known as "BanaVäg Motala-Mjölby", is the case study addressed in this paper. 


\subsection{Motala, Mjölby and BanaVäg}

The municipality of Motala has a population of around 43,000, of which approximately 30,000 live in the town Motala. In recent years, the municipality has seen unemployment rise as large industrial production moved away from the town. In contrast, the municipality of Mjölby has - after a decline in the 1990s - enjoyed growth and consolidated its position in the region. The municipality of Mjölby has several urban conurbations, the largest of which is Mjölby itself, with over 12,000 residents comprising approximately $47 \%$ of the municipal population. The other significant towns in the municipality are the historic town of Skänninge (population approx. 3,200 (12\%); located between Mjölby and Motala, see Figure 1) and Mantorp (approx. 3,700 (14\%); located midway between Mjölby and Linköping). Mjölby and Mantorp were connected to the commuter rail network prior to "BanaVäg", whereas Skänninge and Motala were not. In addition, the three towns in Mjölby municipality are also located close to the E4, the main arterial highway in Sweden, and as such, serve as hubs for highway services and logistics, and commuter towns that are increasingly integrated in the wider regional markets for employment, education and housing. In addition, Mjölby and Motala were connected by "Riksväg 50", a two-lane highway running north from the E4 at Mjölby to Motala, and a goods railway line that forms part of the European TEN network.

The "BanaVäg" project comprised of various significant infrastructure investments aiming to improve the capacity and quality of both the road and rail infrastructure including - the rebuilding and rerouting of the national highway "Riksväg 50"; the construction of a road bridge bypass to the west of Motala town; the downgrading of the old highway through Motala city centre to a local road; and the extension of railway capacity with construction of a second line between Motala and Mjölby. This enabled Motala and Skänninge to be connected to the regional commuter train network.

\section{Methods}

The authors were commissioned by the DAR programme to conduct a qualitative comparative study of the impacts of the BanaVäg project on topics including spatial planning, strategic planning, governance and transportation in the municipalities of Motala and Mjölby. The report is based on the findings of a document and interview study conducted during 2015 (see Table 1), and the findings are presented in a Swedish-language report (Hermelin et al., 2015). The project requirements meant that only informants based in the municipalities were interviewed and other organisations operating in the region (such as the regional public transport body or neighbouring municipalities) were not interviewed, nor were national actors. The project thus provided a qualitative, comparative and exploratory assessment of the perspectives of the two municipalities, whilst leaving some questions open for future studies to explore.

$<<$ Insert Table 1 here $>>$

For the document study, a mix of planning documents and related material were selected following discussions between the researchers and municipal representatives. The documents broadly fall under two categories: strategic planning and physical planning. Examples of strategic planning documents include municipal area plans or executive (i.e. politically approved) action plans. Such documents are typically non-binding, visionary, and medium-long term in character. In contrast, physical planning documents comprised a selection of detailed development plans for each municipality that aimed to broadly represent the range of physical planning actions in the 
municipalities. Detailed development plans provide the legal basis for developments and are valid for five years from the date of council approval.

The processes to develop each type of document typically include various stages of consultation, albeit with differing degrees of regularity and formality. There is a degree of uniformity to detailed development plans, which broadly maintain a similar structure and address similar topics in order to demonstrate that the planning process has served its functions in accordance with the law, whereas strategic plans display more variation in both form and content. In total, the document study focused on 25 municipal documents (see Table 1). For each document, the researchers attempted to identify the main goals, objectives and measures, as well as challenges or opportunities and links to the BanaVäg project or the broader objectives of DAR (i.e. regional development).

Information collected from the document study was complemented with semi-structured individual and group interviews, which served to deepen understanding of the overall context and specific issues or plans. An interview guide, informed by the document study, was developed and provided an overview of illustrative questions and themes, as well as a list of the documents studied.

This was distributed to each interviewee to inform them about the project. Potential interviewees were identified following discussions between the researchers and municipal representatives. These individuals represented different stakeholder groups, such as politicians, civil servants, or local businesses, who in most cases had been participants in the development of municipal strategic planning and/or physical planning. In total, 18 respondents - nine from each municipality - were interviewed (see Table 1). The majority of these interviews were individual and all interviews were recorded and transcribed. Responses were then logged in spreadsheets, enabling structured thematic analysis.

It is important to note that - whilst this paper focuses on sustainable mobility - the document study and interviews had a wider scope and addressed a broader range of topics related to transport infrastructure and urban or regional development. For this reason, this study does not claim to make a comprehensive study of sustainable mobility in each municipality, but rather to focus on the ways in which sustainable mobility is embedded - or not - in broader discussions, and whether or not the status or importance of sustainable mobility increases or diminishes as municipalities move from strategic planning to physical planning.

This informs conclusions concerning the extent to which municipal objectives for sustainable mobility are supported or undermined by provision of national transport infrastructure. Moreover, the focus on sustainable mobility offers "scope to think critically about the ways in which presence and absence are not absolute or necessarily opposed, but rather exist in relation to each other" (McCann and Ward, 2015: 829). Indeed, the presence of absence may indicate the need for new approaches to ensure coherent implementation, rather than selective adoption, of strategic objectives in physical planning processes. In this study, the extent to which sustainable mobility appears and disappears within strategic and physical planning is understood to offer indications as to the extent to which socio-economic considerations are prioritized over issues assumed to be more "environmental" in character, or less obviously socio-economically beneficial.

It should also be noted that, whilst many of the details of this study are specific to the case itself, many of the issues at observed have relevance to similarly-sized municipalities in other contexts. 
According to CEMR (2009), the average municipality in Europe has an area of around $50 \mathrm{~km}^{2}$ and a population of 5,410 residents. Motala and Mjölby are, in terms of both population and area, somewhat larger, and each municipality is less densely populated than the European average. However, as there are over 90,000 sub-national governments in the EU, and around $40 \%$ of these are in France (CEMR, 2009), it is fair to conclude that the case described in this study will have relevance to a cross-section of similarly-sized or populated municipalities in other parts of Europe or elsewhere.

\section{Results}

The study proceeds now with a presentation of results from the document and interview studies, followed by analysis, conclusions and implications for research. In the following section, results are presented by municipality and type, i.e. strategic documents, physical planning documents, and interviews. The results are followed by a comparative discussion that informs the conclusions.

\subsection{Motala - strategic planning documents}

The six strategic planning documents assessed in this study focus strongly on the town Motala and consider the infrastructure constructed in BanaVäg as a critical enabling factor not just for the town's development, but also for the municipality and the western part of the County. A summary of the key topics and themes addressed by four of these strategic planning documents is provided in Table 2. The two other documents are Area Plans proposing developments on the periphery of Motala town and are discussed with reference to the corresponding detailed development plans in section 5.2. $<<$ Insert Table 2 here $>>$

As Table 2 indicates, the theme of renewal is central to recent strategic planning documents. The municipality considers itself to be in "recovery" phase following a period of setbacks and decline, and has invested significant time and resources in a series of efforts to raise the its profile and improve its infrastructure and qualities. Examples include the process to develop a future vision for the town Motala and its city centre, which included a wide-ranging consultation process with the local community, or the municipality's cooperation with local businesses through a business development agency. Such actions have resulted in the development of a dedicated brand that aims to emphasise the geographic location and urban and natural qualities of the town and municipality.

Sustainable mobility is prominently discussed and conceptually central to the long-term visions for the town and town centre, as well as the municipal Masterplan. The topic features to a lesser degree in the political objectives (LDP), and to a much lesser extent with regard to the Area Plans.

The Town Vision identifies the new commuter railway station as a critical node for both sustainable mobility and urban development; yet at the same time, the municipality promotes establishment of new areas for industry and commerce along the highway, implying that the BanaVäg project will facilitate an increase in the number of journeys by car. Similarly, despite its strong emphasis on walking, cycling and public transport, the Town Centre Vision 2025 repeatedly reiterates the need to ensure accessibility is guaranteed for cars.

In both cases, there appears to be an underlying assumption that, in line with the Masterplan (2006), provision of cycling infrastructure would, in combination with the municipality's parking strategy, ensure a reduction in use of cars for short trips. However, the LDP (2015) indicates that this approach has been unsuccessful. Moreover, the LDP is not overtly explicit about its approach to implementing 
the sustainable mobility visions of the other documents. This indicates that, when shifting from more visionary to operational questions, sustainable mobility is a lower priority than other issues, such as employment; similarly, the topic appears to be a low priority for local politicians when planning short-term actions.

\subsection{Motala - detailed development plans}

Detailed development plans provide the legal basis for developments (i.e. construction of new premises or residences) to proceed. Thus, in contrast to the strategic planning documents - which identify aims and ambitions along with possible pathways to achieving such objectives - detailed development plans play a more explicit role in shaping the physical environment. Seven of Motala's detailed development plans were studied, of which four concerned urban development projects close to the railway station and three concerned projects close to the highway (an industrial area, a tourist attraction, and district street planning).

The area close to the railway station is considered critical to the municipality's Town vision and Town Centre Vision 2025. This area was previously divided from the town centre by the highway. With the construction of the bypass and connection to the commuter rail network, Motala aims to integrate the station into an enlarged town centre and develop the district around the station as an attractive site for business and residences (see e.g. Linden, 2015). Each of the four detailed development plans emphasises the need to improve conditions for pedestrians, cyclists and public transport users. However, the plans also strongly emphasise the role of cars, with provisions for e.g. residential parking, commuter parking for train users, taxis.

New buildings are designed to include underground parking areas, perhaps revealing assumptions that investment is contingent on meeting user requirements which may or not reflect user needs or societal goals; there is thus enormous concern to provide parking capacity to meet demand, rather than to restrict capacity and influence demand. Similarly, the plans allow for dispensations from national rules on protected access to waterzones and amendments to a Natura 2000 area to enable inter alia provision of parking spaces (see e.g. plans for Telegrafen, 2008; Centralstationen, 2013).

Another illustration of the tendency to consolidate conditions for car users is provided by the plan Linden (2015) in which it is noted that the municipality's "Guidelines for Parking Needs" will be used to determine provision. The same plan also notes that the municipality lacks guidelines for cycle parking and refers to the corresponding guidelines from Linköping Municipality (Linden, 2015: 15). The Linköping guidelines for cycles stipulate that 14 cycle spaces shall be provided per $1000 \mathrm{~m}^{2}$ for retail premises, whereas Motala's parking guidelines provide for 15 car parking spaces per $1000 \mathrm{~m}^{2}$. In other words, the plan provides for more car parking spaces than cycle parking - this despite low levels of use for existing car parking spaces in the area (Linden, 2015: 21). It is unclear to what extent this occurs in other plans, as these are unclear about the exact numbers of cycle parking spaces provided for.

The other three detailed development plans concern areas on the town's periphery, close to the highway's new route. One of these plans (Norrsten, 2013) concerns expansion of an industrial area and is presented with reference to a planned intermodal freight terminal, as the site is located where the highway and railway cross. The plan also states that existing bus timetables enable workers to travel to and from the site to towns in the region, and allocates resources for investments in 
pedestrian and cycle paths. However, it is clear that the primary purpose of this plan is to facilitate development that is closely linked to road transport. Similarly, both of the other plans make provisions for sustainable mobility (e.g. in the form of a bridge for pedestrians and cyclists on a passage "that is one of Motala's most important cycle tracks" and faced being blocked by the new highway. Bispgatan, 2013: 13) yet the question of public transport provision is not addressed and the overall effect of these plans appears to promote car dependency.

\subsection{Motala - interviews}

The interviews in Motala appear to confirm the results of the document study and suggest sustainable mobility is an example of a strategic objective that becomes progressively less prominent as planning processes move from strategy to detail. There was a strong degree of consensus among interviewees that the BanaVäg project had resulted in immediate effects and that the infrastructure plays a profoundly important role in shaping Motala's future, both locally and in the region. Interviewees cited examples of new development being planned in areas which were previously unreachable because of limited road infrastructure, or undesirable due to the barrier effect caused by the highway running through the town centre. Unsurprisingly, after decades hoping for change, there was strong consensus that change will lead to improvements. However, there was limited reflection concerning the implications (e.g. in terms of inducing demand) of such developments on the municipality's strategies for sustainable mobility.

In general terms, interviewees referred to previous cooperation with the Swedish Transport Administration on sustainable mobility and the municipality's ambition to increase sustainable mobility in tandem with the infrastructure investments. The importance of improving access and safety for pedestrians and cyclists in and around the town centre was discussed, particularly with reference to links between the station, quayside and town square. Regional and tourist cycling were also identified as important priorities. Commuting by train was considered primarily an important platform for municipal development, with the possibility to increase sustainable mobility both within and outside the municipal boundary a secondary effect. Challenges for the town and regional bus services were discussed in relation to the train station and a relocation of bus stops that perhaps will affect retailers in the town centre.

With regard to motorised traffic and especially cars, the interviewees suggested that it is unrealistic to expect residents in a municipality such as Motala to avoid car use; and that it is not possible for a town of Motala's size to restrict access for cars, due to supposed impacts on retail or tourism. One interviewee claimed cost-free parking at the railway station supported sustainable mobility as users were completing their journeys by train, i.e. the parking played the role of a park-and-ride service. Such comments suggest a certain insouciance concerning cars and indicate that participating actors at the municipal level disregard or down-prioritise the importance of sustainable mobility, in direct contradiction of the strategies they helped develop or are obliged to implement.

\subsection{Mjölby - strategic planning documents}

Table 3 provides an overview of key topics and themes addressed by four of the five strategic planning documents concerning Mjölby. The fifth document, an Area Plan, is related to one of the detailed development plans described in section 5.5.

$<<$ Insert Table 3 here $>>$ 
The strategic planning documents attempt to balance local interests and the polycentric structure of the municipality and its economy, which encompasses e.g. Mjölby's industry, retail, and agriculture in rural areas, with its proximity to national infrastructure. Vision Mjölby 2025 (2010) outlines the municipality's main strategies and the importance of infrastructure both now and in the future. At the same time, the document promotes consolidation and improvement of the municipality's qualities, i.e. the character and atmosphere of small towns. These themes are developed in the development programme for Mjölby town, We meet in Mjölby (2015), which attempts to identify strategies to improve the urban qualities of Mjölby town centre.

Interestingly, the only reference to the municipality's nine targets for energy and climate for the period 1990-2025, which include reducing $\mathrm{CO}_{2}$ emissions per resident by $60 \%$, increasing residents' journeys by public transport and the number of cyclists by $20 \%$, and reducing residents' car use by $20 \%$, is in an Area Plan (Skänninge, 2014: 36). These targets are not discussed in the other recent strategic documents. However, each of the strategy documents strongly emphasises the need to increase levels of sustainable mobility and reduce use of cars for short or local journeys. The extent to which these objectives are integrated into physical planning is explored below.

\subsection{Mjölby - detailed development plans}

Three of the studied detailed development plans address projects in Mjölby town, and three concern projects on the town's periphery. The seventh plan concerns a development project in Skänninge.

The plans addressing projects in the town centre (Rosenkammaren, 2014; Tumskruven, 2009) make provisions for use of street space and cycling, whilst expressing concern about noise levels close to the railway. The plans are vague about the exact numbers of cycle parking spaces provided, yet explicit about car parking; indeed, in Rosenkammaren (2014), space is specifically reserved for car parking, which (it appears) is considered an inherent part of any construction project.

The third town project (Sjunningsfält, 2014) proposes construction of new residences and a school in an area southeast of the town centre. This plan also makes specific references to the use of street space, traffic safety, and accessibility for pedestrians, cycles and public transport. At the same time, the plan allows for significant traffic movements by cars, underpinned by an assumption that parents need to use cars to leave their children at school.

The detailed development plans for the three peripheral sites primarily concern industrial developments. Provisions are made to improve infrastructure for pedestrians and cycles, but the plans acknowledge that expanded operations at locations close to the major highways around Mjölby are likely to induce demand for car parking, implying increased use of cars (e.g. Viringe vast, 2010: 6). The detailed development plan for Skänninge concerns construction of a new supermarket in the town and again, despite making provision to improve infrastructure for non-motorised transport, the plan also "allows a relatively large car park... exposed to a road which is an important entry to the town centre" (Skänninge, 2015: 15).

\subsection{Mjölby - interviews}

Interviews in Mjölby were dominated by discussions concerning issues such as town centre development, regional markets - particularly for housing - and the impact of infrastructure on commuter travel. Public transport was considered a particularly important means of reducing the 
number of journeys by car, a challenge which interviewees argued was difficult for small towns and rural areas to resolve. Most interviewees expressed a strong hope that the commuter train would continue to grow in popularity and that railway infrastructure could be used to divert freight from roads around Skänninge, where a large retail distribution company is located.

In Mjölby, interviewees argued for densification, partly to increase the qualities of the town centre but also to decrease barriers between the centre and residential districts. Walking and cycling were considered important tools to achieve this, and interviewees emphasised the need to expand and improve the network of cycle paths. At the same time, several interviewees stated that the municipality needed to maintain its policy of offering free parking spaces in the entire municipality, as this offers a competitive advantage vis-a-vis Linköping and Motala. One interviewee stated that shop owners are "afraid that the municipality will close the street" and another argued that the town centre is too small to prevent cars entering. Another interviewee remarked that cars using the national highway have led to an "explosion" of activity at one of the peripheral sites, and that fuel sales in the municipality exceed the amount residents can use, meaning that there is a significant share of through traffic using facilities at this location.

\section{Discussion}

This study suggests that efforts to increase sustainable mobility at the local level face numerous challenges. The results highlight inconsistency in both the planning and implementation of municipal strategies. For example, each of the studied municipalities declares its intention to decrease use of cars and promote sustainable mobility, and incorporates these objectives into strategic and physical planning. However, sustainable mobility has a significantly strong "presence" in strategic planning than in physical planning, whereas the need for motorised transportation is emphasised and facilitated by both strategic and physical planning in a more explicit way. Both municipalities are thus less than rigorous in using physical planning to enforce implementation of measures to promote sustainable mobility and fulfil strategic objectives.

This is not to say the municipalities do nothing to improve conditions for sustainable mobility, but rather that they continue to consolidate and in some cases improve conditions for motorists, particularly in peripheral zones close to major highways. For example, each municipality views town centres as arenas for sustainable mobility, and sustainable mobility as a vector for town centre development, alongside the physical attributes of the town and its service offerings. In contrast, motorised transport - particularly cars - are considered undesirable in town centres; indeed, in Motala, one of the main purposes of the BanaVäg road investment was to redirect cars and trucks away from the town centre.

Nevertheless, in both municipalities, strategies and plans make significant efforts to justify continued access for cars and continued investment in infrastructure for cars, e.g. in the form of parking spaces, in and around town centres. These efforts redirect resources - in terms of money, space and time from other, more sustainable modes of transport. Moreover, they are likely to consolidate or induce demand for journeys by car. Both municipalities motivate such decisions by emphasising the particularity of local contexts, yet the trend has also been observed in other studies (Berger et al., 2009; Hrelja et al., 2015; Hysing, 2009; Isaksson and Storbjork, 2012). 
Outside of the town centres, the results indicate a strong consolidation of existing trends. The BanaVäg project has significantly improved road infrastructure and enabled an expansion of the commuter rail network which, though increasing passenger numbers on one "sustainable" transport mode, has partly resulted in a reallocation of resources in regional public transport. This in turn has resulted in a diminished regional bus service, reinforcing the likelihood that many people living outside of - and on the peripheries of - the municipalities' urban conurbations will prefer to use cars.

Both municipalities have attempted to improve conditions for intra-municipal and regional cycling, yet the reuse of discontinued railway infrastructure or old roads for cycling - whilst cars travel on recently refurbished roads - implies cycles have a lower status than cars. Moreover, cycle paths linking sites already connected by public transport (or vice versa) run the risk of generating direct competition between sustainable modes of transport, rather than attracting new users from cars.

Moreover, the national investment in improved road infrastructure has, as noted above, improved access for automobiles to sites in peri-urban areas. Each municipality has chosen to pursue new developments in the proximity of the road corridor, developments that would not have occurred in the absence of road infrastructure. However, the detailed development plans for these areas suggest limited efforts to prioritise sustainable mobility. This indicates that, when presented with new infrastructure, local planning is normative and unable to challenge (actual or supposed) path dependencies, whilst local decision-makers prioritise certain strategic objectives (e.g. economic growth, jobs) over others (e.g. densification, sustainable mobility). Such permissive accommodation of automobiles in planning has been observed in other studies, such as Hrelja et al. (2015).

National decisions thus have a direct impact on local development patterns and may curtail the ability, or willingness, of municipalities to pursue sustainable growth strategies which enable e.g. decarbonisation of local transport. It is for example, as several of the interviewees in this study suggested, difficult for municipal politicians to ignore or reject possibilities to create jobs through peri-urban retail or industrial development, even when such development counteracts other municipal objectives. However, the cumulative impact of myriad developments at the municipal level in turn undermines national objectives for e.g. sustainable transportation and climate change. This trend appears to be a path dependency in itself, and indicates a need, both at the municipal and national levels, for conscious, deliberate and systematic effort to overcome it.

The apparent incongruence between strategies' aspirations for sustainable mobility and accommodation of vehicle traffic, along with the gap between strategic objectives and the output or produced reality of physical planning, implies a regular inversion or negation of the order of priorities implied by the principles of sustainable mobility. As noted above, national decisions appear to reinforce this inversion, perhaps due to their emphasis on long-distance transportation along corridors (Holzapfel, 2015). The interviewees did not reflect extensively on this point, although they did indicate a number of concerns, for example the possible impact of changing patterns of mobility and access to parking spaces on retailers.

Other possible reasons include e.g. trade-offs between seemingly conflicting priorities, loss aversion, or assumptions about user preferences or behaviour and related socio-economic impacts (cf. Berger et al. (2009); Hysing (2009); Næss et al., 2011). One justification, appearing in documents and repeated by interviewees in both municipalities, is that towns such as Motala and Mjölby are too 
small to restrict access for cars, a statement that appears to somewhat conflict with statements about how the short distances in such towns are ideal for walking or cycling.

Results from other studies suggest that municipal actors may employ justifications of the kind "we are too big/small" are attribution errors, implying that the underlying reason to avoid restricting access to cars depends on something else (Fenton and Gustafsson, 2015). Given that municipalities often use national targets, such as those concerning climate change, as a means of framing and justifying sustainable mobility, it may be reasonable for national authorities to consider - if most towns are too small or too big to restrict access for cars - whether choice should be replaced with compulsion.

Of course, it may be - as interviewees suggested - somewhat idealistic to think that small municipalities can suddenly or dramatically introduce restrictions for cars at all times and in all contexts, not least because rural populations around urban conurbations are largely dependent on cars. On the other hand, peripheral zones are close to highways and accessible for cars, where the tendency to accommodate cars is strongest. Understanding this increases the importance of being less permissive in not only town centre planning, as town centres are one of few locations where restrictions are practical and possible, but also in peri-urban planning, where new developments are often assumed to be inevitable and usually facilitate increased flows of motorised vehicle traffic. As noted above, a new style of national infrastructure policy and planning may be required to facilitate such a transformation.

The observation that small municipalities are unwilling to take (what they perceive to be) risks concerning, for example, accessibility to retailers in town centres, is perhaps no great surprise. Nonetheless, the point illustrates a broader challenge for transport planning, namely the prevalence of attribution errors, first-mover problems and problem-shifting in planning processes. In other words, small municipalities - such as those studied here - may find it convenient to claim that the particular challenges of their local context inhibit their ability to make decisive shifts towards a stringent application of the sustainable mobility hierarchy and the four-step principle, particularly if acting alone.

This, again, implies coordinated action within the framework of a wider regional or national transition may be required to break away from a path dependency, along with differentiated strategies for different modes of transport (cf. Aditjandra et al., 2013). Similarly, the tendency of individual municipalities to - explicitly or implicitly - absolve themselves of responsibility for local action simply shifts problems elsewhere. This is particularly important with regard to local traffic, which forms part of municipalities' mandates, whereas regional and national traffic flows are seen as a national responsibility.

Returning to national infrastructure, the study highlights the mixed impacts of investments at the local level. Increased railway capacity and the extension of the commuter rail network have enabled new groups of passengers to access the system and undoubtedly promote sustainable mobility. Investment in stations has been used a stimulus for urban development projects and other improvements in infrastructure enabling sustainable mobility. At the same time, municipalities have continued to support use of cars through e.g. street space design and the provision of parking around stations and in new development projects. 
In the same vein, improvements to road capacity have resulted in a range of benefits for the towns studied, not least by the use of bypasses to redirect heavy goods traffic and inter-regional traffic out of town centres in Motala and Skänninge. The re-routing of highways away from town centres improves local environmental conditions in town centres and contributes to the viability of regeneration and development projects. At the same time, the fact that road traffic is still facilitated may mean the new infrastructure has limited local effects, in terms of residents' modal choice. In addition, the improvement of bypasses and limitations of public transport services outside of urban conurbations may consolidate use of cars for intra-municipal, regional and national transport, and contribute to urban sprawl that further counteracts local ambitions concerning sustainable mobility.

\section{Conclusions}

In sum, the challenge of enabling and increasing levels of sustainable mobility appears a vexing problem, counteracted by assumptions, decisions and trade-offs at the municipal level, and by the impacts and implications of national investments in road and rail infrastructure. Addressing this challenge is likely to require more consistent and dedicated efforts from actors at the municipal and other levels of government. Planning tools exist, yet are used in a dysfunctional, ineffective manner.

Although present in municipal strategic planning, sustainable mobility often appears to be defined by its absence from physical planning, which frequently prioritises a perceived need for (rapid) mediumlong distance transport to or from a site ahead of more sustainable modes of transport (which may be ideal for short-medium, local journeys yet are slower or inviable for long-distance transport). This tendency appears to relate to assumptions about the relationship between cars, parking and retail in urban spaces, and access to regional or national markets. Moreover, improvements to infrastructure facilitating rapid long-distance transportation induce both transportation and service demands across a wider area, making it harder for sustainable modes of transport to compete with motor vehicles on various terms (e.g. accessibility, availability, cost, viability).

In this study, such effects are observed in for example, continued provision of new parking spaces in and around town centres; declining provision of regional bus services whilst commuter rail services are improved; and urban sprawl alongside new or improved highways. Of course, sustainable mobility should not be understood to be a panacea for all transport challenges. Indeed, the order of priorities emphasises motorised transport as an alternative, albeit one of last resort, to be used for essential transportation where no more sustainable alternative is viable. Nevertheless, as this study has shown, assumptions and norms tend to invert the order of priorities, and politicians and planners may need to be more stringent in maintaining the sustainable mobility hierarchy and enforcing the four-step principle if a transition to sustainable mobility is to be achieved at the local level.

Should municipalities prove themselves unwilling or incapable of doing this, it may be necessary for national governments to consider obliging them to do so. Moreover, it may be possible to develop alternative forms on national and regional transport infrastructure planning that play a more supportive role in facilitating local transitions to sustainable mobility and which emphasise investments in sustainable (and/or essential) medium-long distance transport, rather than provision of accessible infrastructure that induces unsustainable (and/or non-essential) forms of transportation. However, in the absence of such alternatives, national transport planning is likely to focus on decarbonisation of (motorised) transportation and promoting efficient use of infrastructure, 
measures which - although commendable - are unlikely to have a profound impact on municipal planning for sustainable mobility and sustainable urban development.

\section{Acknowledgements}

The author wishes to thank the Swedish Transport Administration for funding this research, the interviewees in the two municipalities, along with Brita Hermelin and Terje Ragnarsson, the coauthors of the Swedish language report. the interviewees in the two municipalities and without whose collaboration this paper would not exist. Special thanks go to two anonymous reviewers whose comments have improved the paper.

\section{References}

Aditjandra, P.T. (2013) The impact of urban development patterns on travel behaviour: Lessons learned from a British metropolitan region using macro-analysis and micro-analysis in addressing the sustainability agenda. Research in Transportation Business and Management, 7:69-80.

doi:10.1016/j.rtbm.2013.03.008

Aditjandra, P. T., Mulley, C., Nelson, J. D. 2013. The influence of neighbourhood design on travel behaviour: Empirical evidence from North East England. Transport Policy, 26:54-65.

doi:10.1016/j.tranpol.2012.05.011

Antonson, H., Isaksson, K., Storbjörk, S., Hjerpe, M. (2016). Negotiating climate change responses: Regional and local perspectives on transport and coastal zone planning in South Sweden, Land Use Policy, 52: 297-305. DOI: 10.1016/j.landusepol.2015.12.033

Banister, D. (2011). The trilogy of distance, speed and time, Journal of Transport Geography, 19, 950959.

Banister, D., Berechman, Y. (2001). Transport investment and the promotion of economic growth, Journal of Transport Geography, 9(3), 209-218.

Berger, G., Feindt, P.H., Holden, E., Rubik, F. (2014). Sustainable Mobility-Challenges for a Complex Transition, Journal of Environmental Policy \& Planning, 16(3) 303-320, DOI:

10.1080/1523908X.2014.954077

Bertolini, L., de Clercq, F. (2003). Urban development without more mobility by car? Lessons from Amsterdam, a multimodal urban region, Environment and Planning A, 35, pp. 575-589.Cantos, P., Gumbau-Albert, M., Maudos, J. (2005). Transport infrastructures, spillover effects and regional growth: evidence of the Spanish case, Transport Reviews, 25 (1) 25-50. DOI:

10.1080/014416410001676852 
CEMR - Council of European Municipalities and Regions. (2009). Local and regional authorities Balancing democracy, identity and efficiency - Changes in local and regional structures in Europe. Brussels: CEMR.

Dannenberg, A.L., Jackson, R.J., Frumkin, H., Schieber, R.A., Pratt, M., Kochtitzky, C., Tilson, H.H. (2003). The Impact of Community Design and Land-Use Choices on Public Health: A Scientific Research Agenda, American Journal of Public Health, 93(9): 1500-1508.

De Flander, K. Closed Cycles - Open City. In: Johnson, C., Toly, N., Schroeder, H. (2015). The Urban Climate Challenge: Rethinking the Role of Cities in the Global Climate Regime, New York: Routledge, 37-59.

European Union, 2011. Cities of tomorrow - Challenges, visions, ways forward, Brussels: European Commission, Directorate General for Regional Policy.

Fenton, P. Gustafsson, S. (2015). Contesting sustainability in urban transport - perspectives from a Swedish town. Natural Resources Forum, 39(1) 15-26. DOI: 10.1111/1477-8947.12061

Gao, J., Kørnøy, L., Christensen, P. (2013). The politics of strategic environmental assessment indicators: weak recognition found in Chinese guidelines, Impact Assessment And Project Appraisal, 31 (3), 232-237. DOI: 10.1080/14615517.2013.786925

Gudmundsson, H., Hall, R.P., Marsden, G., Zietsman, J. (2016). Sustainable Transportation: Indicators, Frameworks, and Performance Management, Berlin: Springer-Verlag.

Goldman, T., Gorham, R. (2006). Sustainable urban transport: Four innovative directions. Technology in Society, 28, 261-273.

Hermelin, B., Fenton, P., Ragnarsson, T. (2015) Infrastrukturinvesteringar, kommunal planering och hållbar samhällsutveckling: erfarenheter från BånaVäg Motala-Mjölby. Borlänge: Swedish Transport Administration, 2015 (156).

Hickman, R., Banister, D., 2014. Transport, Climate Change and the City, Routledge, Abingdon

Hiselius, L.W., Rosqvist, L.S. (2016) Mobility Management campaigns as part of the transition towards changing social norms on sustainable travel behavior, Journal of cleaner production, 123(1): 34-41.

Holzapfel, H., 2015. Urbanism and Transport: Building Blocks for Architects and City and Transport Planners. Abingdon: Routledge.

Hrelja, R., Hjerpe, M., Storbjörk, S. (2015) Creating Transformative Force? The Role of Spatial Planning in Climate Change Transitions Towards Sustainable Transportation. Journal of Environmental Policy \& Planning, 1-19. DOI: 10.1080/1523908X.2014.1003535

Hysing, E., Frändberg, L., Vilhelmson, B. (2015) Compromising sustainable mobility? The case of the Gothenburg congestion tax, Journal of Environmental Planning and Management, 58:6, 1058-1075, DOI: 10.1080/09640568.2014.912615

Hysing, E. (2009). Greening Transport-Explaining Urban Transport Policy Change. Journal of Environmental Policy \& Planning, 11(3): 243-261. DOI: 10.1080/15239080903056417 
Isaksson, K., Storbjörk, S., (2012). Strategy making and power in environmental assessments. Lessons from the establishment of an out of town shopping centre in Västerås, Sweden. Environmental Impact Assessment Review, 34, 65-73.

Kenworthy, J.R. (2003). Transport energy use and greenhouse gases in urban passenger transport systems: A study of 84 global cities. Available from:

http://www.naturaledgeproject.net/Documents/KenworthyTransportGreenhouse.pdf (accessed 8 December 2015).

Knudsen, M.A., Rich, J. (2013). Ex post socio-economic assessment of the Oresund Bridge. Transport Policy, 27, 53-65.

Köhler, J., Whitmarsh, L., Nykvist, B., Schilperoord, M., Bergman, N., Haxeltine, A. (2009). A transitions model for sustainable mobility. Ecological Economics, 68, 2985-2995.

Lakshmanan, T.R. (2011). The broader economic consequences of transport infrastructure investments. Journal of Transport Geography, 19 (1): 1-12.

Lindenau, M., Böhler-Baedeker, S. (2014) Citizen and stakeholder involvement: a precondition for sustainable urban mobility. Transportation Research Procedia, 4, 347-360.

Lundqvist, L.J., von Borgstede, C. (2008). Whose Responsibility? Swedish Local Decision Makers and the Scale of Climate Change Abatement, Urban Affairs Review, 43(3): 299-324.

McCann E, Ward K. (2015). Thinking Through Dualisms in Urban Policy Mobilities. International Journal of Urban and Regional Research, 39(4): 828-830. doi:10.1111/1468-2427.12254.

McIntosh, J., Trubka, R., Kenworthy, J., Newman, P. (2014). The role of urban form and transit in city car dependence: Analysis of 26 global cities from 1960 to 2000. Transportation Research Part D:

Transport and Environment, 33, 95-110.

Municipality of Mjölby

- 2009. Detaljplan för fastigheten Tumskruven 1 i Mjölby (Tumskruven)

- 2010. Detaljplan för Viringe industriområde, västra delen (Viringe väst)

- 2010. Vision Mjölby kommun 2025 (Vision Mjölby 2025)

- 2011. Översiktsplan för Mjölby kommun (Masterplan)

- 2012. Vision 2025 Svartå Strand - Fördjupning av översiktsplanen för del av Mjölby centrum (Masterplan Svartåstrand)

- 2013. Detaljplan för Viringe industriområde, södra delen (Viringe syd)

- 2013. Detaljplan för del av kvarteren Yxan och Symaskinen i Mjölby (Yxan)

- 2014. Detaljplan för kvarteret Rosenkammaren, Svartå strand (Rosenkammaren)

- 2014. Detaljplan för Sjunningsfält, Mjölby (Sjunningsfält)

- 2014. Samrådshandlingar för den fördjupad översiktsplan i Skänninge (Skänninge, 2014)

- 2015. Detaljplan för del av Skänninge 3:2 m.fl. Skänninge (Skänninge, 2015)

- 2015. Vi möts i Mjölby - Utvecklingsprogram för Mjölbys stadskärna (We meet in Mjölby)

Available at: http://www.mjolby.se/

Municipality of Motala

- 2006. Motala möter framtiden - Översiktsplan för Motala Kommun (Municipal Masterplan)

- 2008. Detaljplan för del av Kv. Telegrafen mm. (Telegrafen)

- 2010. Planprogram för Badstrandsvägen mm, Varamon (Area Plan Badstrandsvägen) 
- 2013. Detaljplan för Bispgatans förlängning, trafikplats Metallvägen mm (Bispgatan)

- 2013. Detaljplan för Motala Centralstation mm, Östermalm (Centralstation)

- 2013. Detaljplaneprogram för Norrstens verksamhetsområde (Area Plan Norrsten)

- 2013. Detaljplan för Norrstens verksamhetsområde, etapp 1, Norrsten (Norrsten)

- 2013. Detaljplan för Östra Varamobaden, etapp 1 (Östra Varamobaden)

- 2014. Detaljplan för Kv. Ingenjören, Östermalm (Ingenjören)

- 2014. Motala Centrum 2025 - Vår gemensamma vision + Tillhörande samrådsredogörelse (Town Centre Vision)

- 2014. Stadsvision Motala (Town Vision)

- 2015. Detaljplan för Kv. Linden, Östermalm (Linden)

- 2015. Lokal utvecklingsplan 2015-2018 (Local Development Programme 2015-2018)

Available at: http://www.motala.se/kommun

Næss, P., Strand, A., Næss, T., \& Nicolaisen, M. 2011. On their road to sustainability?: The challenge of sustainable mobility in urban planning and development in two Scandinavian capital regions. Town Planning Review, 82(3):285-316. doi:10.3828/tpr.2011.18

Nilsson, J-E., Pyddoke, R., Swärdh, J-E. (2012). Fyrstegsprincipen i praktiken - Tre underlagsrapporter för Riksrevisionens granskning av transportpolitiken, Linköping: Statens väg- och transportforskningsinstitut.

Rasouli, S., Timmermans, H.(2015). Frontiers in Modelling Bounded Rationality in Travel Behaviour Research: Introduction to the Collection of Papers. In: Rasouli S., Timmermans, H.J.P. Eds, Bounded Rational Choice Behaviour: Applications in Transport. Bingley: Emerald Group Publishing, 213-230.

Richardson, B.C. (2005) Sustainable transport: analysis frameworks. Journal of Transport Geography, 13, 29-39.

Robertson, K. (2015) Comparison of the EU's Sustainable urban mobility plan (SUMP) and the Swedish planning support Transport for an attractive city (TRAST). Linköping: Statens väg- och transportforskningsinstitut.

Schwanen, T., Banister, D., Anable, J. (2011). Scientific research about climate change mitigation in transport: A critical review. Transportation Research Part A: Policy and Practice, 45 (10): 993-1006.

SCB (Statistics Sweden). (2014) Statistisk årsbok 2014. Stockholm: SCB, 86-87.

Swedish Transport Administration, 2015. Available at: http://www.trafikverket.se/for-dig-ibranschen/Planera-och-utreda/samhallsplanering1/samspel-mellan-trafik-och-bebyggelse/Planerafor-hallbara-stader-och-attraktiva-regioner/Den-attraktiva-regionen/vad-handlar-den-attraktivaregionen-om/ accessed 26 October 2015.

UN-Habitat. (2012). Urban Planning for City Leaders. Nairobi: UN-Habitat.

Van Acker, V., Derudder, B., \& Witlox, F. (2013) Why people use their cars while the built environment imposes cycling. The Journal of Transport and Land Use, 6(1):53-62.

doi:10.5198/jtlu.v6i1.288

Wefering, F., Rupprecht, S., Buhrmann, S., Bohler-Baedeker, S., 2014. Guidelines. Developing and Implementing a Sustainable Urban Mobility Plan. European Commission, Brussels. 
Woodcock, J., Edwards, P., Tonne, C., Ashiru, O., Banister, D., Beevers, S., Chalabi, Z., Chowdhury, Z., Cohen, A., Franco, O.H., Haines, A., Hickman, R., Lindsay, G., Mittal, I., Mohan, D., Tiwari, G., Woodward, A., Roberts, I. (2009). Public health benefits of strategies to reduce greenhouse-gas emissions: urban land transport. The Lancet, 374 (9705): 1930-1943.

Wollmann, H. (2008). Reformen in Kommunalpolitik und- Verwaltung. England, Schweden, Frankreich und Deutschland im vergleich / Comparing Local Government Reforms in England, Sweden, France and Germany. Wiesbaden: VS Verlag.

World Bank. (2010). Cities and Climate Change: an urgent agenda. New York: The International Bank for Reconstruction and Development/ The World Bank. 
Table 1: Overview of main sources used to conduct document and interview study.

\begin{tabular}{|c|c|c|c|c|c|c|c|c|}
\hline & \multicolumn{4}{|c|}{ Document study } & \multicolumn{4}{|c|}{ Interview study } \\
\hline Municipality & \multicolumn{2}{|c|}{ Strategic plans } & \multicolumn{2}{|c|}{ Physical plans } & \multicolumn{2}{|c|}{$\begin{array}{l}\text { Municipal } \\
\text { representatives } \\
\text { (politicians / civil } \\
\text { servants) }\end{array}$} & \multicolumn{2}{|c|}{ Other stakeholders } \\
\hline Motala & 6 & $\begin{array}{l}\text { Local Development } \\
\text { Programme 2015-2018 } \\
\text { (2015); Municipal } \\
\text { Masterplan (2006); } \\
\text { Town Vision (2014); } \\
\text { Town Centre Vision } \\
\text { (2014); Area Plans } \\
\text { (Badstrandsvägen, 2010; } \\
\text { Norrsten, 2013) }\end{array}$ & 7 & $\begin{array}{l}\text { Bispgatan (2013); } \\
\text { Centralstation (2013); } \\
\text { Ingenjören (2014); } \\
\text { Linden (2015); } \\
\text { Norrsten (2013); } \\
\text { Telegrafen (2008); } \\
\text { Östra Varamobaden } \\
\text { (2013) }\end{array}$ & 6 & $\begin{array}{l}2 \text { politicians ( } 2 \\
\text { parties); } 4 \text { civil } \\
\text { servants } \\
\text { (senior } \\
\text { managers and } \\
\text { strategists) }\end{array}$ & 3 & $\begin{array}{l}\text { Representing } \\
\text { city centre } \\
\text { business } \\
\text { group; } \\
\text { economic } \\
\text { development } \\
\text { agency; } \\
\text { housing } \\
\text { association }\end{array}$ \\
\hline Mjölby & 5 & $\begin{array}{l}\text { Masterplan (2011); } \\
\text { Masterplan Svartåstrand } \\
\text { (2012); Masterplan } \\
\text { Skänninge (2012); Vision } \\
\text { Mjölby } 2025 \text { (2010); We } \\
\text { meet in Mjölby (2015) }\end{array}$ & 7 & $\begin{array}{l}\text { Rosenkammaren } \\
\text { (2014); Sjunningsfält } \\
\text { (2014); Skänninge } \\
\text { (2015); Tumskruven } \\
\text { (2009); Viringe väst } \\
\text { (2010); Viringe syd } \\
\text { (2013); Yxan (2013) }\end{array}$ & 5 & $\begin{array}{l}2 \text { politicians } \\
\text { (two parties); } \\
3 \text { civil servants } \\
\text { (managers) }\end{array}$ & 4 & $\begin{array}{l}\text { Representing } \\
\text { city centre } \\
\text { business group } \\
\text { (2); retailer; } \\
\text { housing } \\
\text { association }\end{array}$ \\
\hline
\end{tabular}




\begin{tabular}{|c|c|c|c|c|c|}
\hline Document* & Date & $\begin{array}{l}\text { Area of } \\
\text { focus }\end{array}$ & Summary & Examples & \\
\hline $\begin{array}{l}\text { Municipal } \\
\text { Masterplan }\end{array}$ & $\begin{array}{l}2006-05- \\
22\end{array}$ & $\begin{array}{l}\text { Municip } \\
\text { ality of } \\
\text { Motala }\end{array}$ & $\begin{array}{l}\text { Develop } \\
\text { attractive } \\
\text { conditions for } \\
\text { residents, } \\
\text { investors, and } \\
\text { improve } \\
\text { welfare, } \\
\text { infrastructure }\end{array}$ & 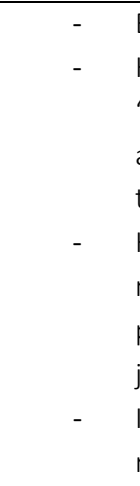 & $\begin{array}{l}\text { Emphasis on Motala's regional role. Aims to improve conditions for commuting to/from the municipality (p.11). } \\
\text { Highway and railway as physical barriers to urban development. Need to move highway "from the town centre" (p.11) yet } \\
\text { "the municipality's influence is limited with regard to infrastructure and communications. The municipality only has full } \\
\text { authority over its road and cycle network and as purchaser of some public transport" (p.38: the latter role has since been } \\
\text { transferred to the regional level). } \\
\text { However, "even if responsibility and resources for providing improved infrastructure primarily lie in others' hands, the } \\
\text { municipality can contribute to successively improving travel options" (p.11) and "it is assumed that the extension of cycle } \\
\text { paths within urban conurbations and the municipality's long-term parking strategy will reduce car dependency for short } \\
\text { journeys" and support an increase in use of public transport (p.46). } \\
\text { Investments in public transport, especially commuter trains, and environmentally-friendly vehicles and fuels, may help } \\
\text { reduce negative impacts of transportation such as } \mathrm{CO}_{2} \text { or } \mathrm{NO}_{x} \text { emissions, congestion, or social pressures (pp. 30-31). }\end{array}$ \\
\hline Town Vision & $\begin{array}{l}2014-10- \\
27\end{array}$ & $\begin{array}{l}\text { Town of } \\
\text { Motala }\end{array}$ & $\begin{array}{l}\text { Urban } \\
\text { development. } \\
\text { Five themes } \\
\text { and three } \\
\text { strategies. }\end{array}$ & $\begin{array}{l}- \\
- \\
- \\
- \\
-\end{array}$ & $\begin{array}{l}\text { Sustainability is both a theme and a strategy. } \\
\text { Town Vision aims to improve structural conditions in Motala and enable economic development, both around the new } \\
\text { station and highway. } \\
\text { Commuter railway station is critical for sustainable mobility and urban development. } \\
\text { Residents should be able "to make the whole journey with public transport" or cycle (p.10). } \\
\text { "Conscious investments" should support town's cycling strategy and "provide safe and secure opportunities to commute } \\
\text { by cycle" to other towns in the region (p.22). } \\
\text { Promote cycle tourism and develop car-free cycle route around Lake Vättern, Europe's fifth-largest lake (p.22). }\end{array}$ \\
\hline $\begin{array}{l}\text { Town } \\
\text { Centre } \\
\text { Vision }\end{array}$ & $\begin{array}{l}2014-10- \\
14\end{array}$ & $\begin{array}{l}\text { Town } \\
\text { centre }\end{array}$ & $\begin{array}{l}\text { Town centre } \\
\text { development, } \\
\text { aim to attract } \\
\text { new residents, } \\
\text { companies, } \\
\text { tourists. }\end{array}$ & $\begin{array}{l}- \\
- \\
- \\
-\end{array}$ & $\begin{array}{l}\text { Bypass means old highway route through town centre can be remodeled, reducing barrier effects, noise, pollution, etc. } \\
\text { Opportunity to consolidate, diversify and densify town centre housing and services. } \\
\text { Motala to be "County's best cycle town" (p.10). } \\
\text { Prioritisation of walking and cycling in town centre should be "visible in the physical space", yet centre should also be a } \\
\text { "hub for all modes of transport" (p.12). } \\
\text { However, "even if cyclists and bus passengers account for an increased share of retailers' turnover, the town centre must } \\
\text { be easy for visitors to reach by car" (p.10). It should "be possible to drive on all streets except pedestrian streets" and } \\
\text { sufficient parking should meet demand "even when needs are greatest" (p.13). }\end{array}$ \\
\hline $\begin{array}{l}\text { Local } \\
\text { Developme } \\
\text { nt } \\
\text { Programme } \\
2015-2018\end{array}$ & $\begin{array}{l}2015-02- \\
23\end{array}$ & $\begin{array}{l}\text { Municip } \\
\text { ality of } \\
\text { Motala }\end{array}$ & $\begin{array}{l}\text { Political } \\
\text { priorities for } \\
2015-2018 \\
\text { mandate } \\
\text { period. }\end{array}$ & $\begin{array}{l}- \\
- \\
-\end{array}$ & $\begin{array}{l}\text { Strong emphasis on local economic development, municipality's role in region and marketing/profile of Motala. } \\
\text { BanaVäg infrastructure is an important enabling factor, but "despite cycle projects and commuting by train, the use of } \\
\text { cars by residents has not reduced" (p.9). } \\
\text { "Climate smart travel" is named as a target area for evaluation, but the LDP is not specific about measures planned to } \\
\text { increase levels of sustainable mobility (p.10). }\end{array}$ \\
\hline
\end{tabular}


Table 2. Overview of key strategic planning documents in Motala. 


\begin{tabular}{|c|c|c|c|c|c|}
\hline Document* & Date & $\begin{array}{l}\text { Area of } \\
\text { focus }\end{array}$ & Summary & Examples & \\
\hline $\begin{array}{l}\text { Vision } \\
\text { Mjölby } 2025\end{array}$ & $\begin{array}{l}2010- \\
06-22\end{array}$ & $\begin{array}{l}\text { Municip } \\
\text { ality }\end{array}$ & $\begin{array}{l}\text { Aims for attractive } \\
\text { settlements in an } \\
\text { expensive region; } \\
\text { emphasis on } \\
\text { quality of life, } \\
\text { sustainable } \\
\text { mobility }\end{array}$ & - & $\begin{array}{l}\text { Emphasises quality of life and character of small towns and their accessibility to/from national transport infrastructure. } \\
\text { Advocates "climate-adapted and energy-efficient" sustainable mobility with cycling "an obvious choice for shorter } \\
\text { journeys" and public transport "a good choice for the majority of journeys". In the near future, "commuting with car will } \\
\text { be dramatically reduced" (р.3). }\end{array}$ \\
\hline Masterplan & $\begin{array}{l}2011- \\
08-23\end{array}$ & $\begin{array}{l}\text { Municip } \\
\text { ality }\end{array}$ & $\begin{array}{l}\text { Emphasis on } \\
\text { development } \\
\text { through e.g. } \\
\text { housing, } \\
\text { premises, } \\
\text { infrastructure and } \\
\text { regional markets }\end{array}$ & $\begin{array}{l}- \\
- \\
- \\
- \\
-\end{array}$ & $\begin{array}{l}\text { Describes municipality's past investments in infrastructure for walking, cycling, and its travel centre for bus and train. } \\
\text { Increased "cycling, use of commuter trains and a future high-speed rail link will improve contacts with the world" and } \\
\text { "facilitate daily life without local car journeys" (pp. 75-76). } \\
\text { Identifies a need to extend intra-municipal and regional cycle networks and improve conditions for public transport. } \\
\text { "Pedestrian and cycle paths are important within the towns, where the extension of comfortable and secure cycle paths } \\
\text { shall continue with priority given to destinations such as schools, the town centre and train stations" (p.50). } \\
\text { Streets in the town centre "should prioritise pedestrians and reduce the negative impacts of cars" (p.52). } \\
\text { Proposes new speed limits for cars in towns of Mjölby, Mantorp and Skänninge. Notes that the Swedish Transport } \\
\text { Administration is responsible for speed limits and roads in other conurbations with the municipality (p.51). }\end{array}$ \\
\hline $\begin{array}{l}\text { We meet in } \\
\text { Mjölby } \\
\text { (consultatio } \\
n \\
\text { document) }\end{array}$ & $\begin{array}{l}2015- \\
06-05\end{array}$ & $\begin{array}{l}\text { Mjölby } \\
\text { town } \\
\text { centre }\end{array}$ & $\begin{array}{l}\text { Vision for } \\
\text { attractive town } \\
\text { centre; emphasis } \\
\text { on traffic and } \\
\text { accessiblity }\end{array}$ & $\begin{array}{l}- \\
- \\
- \\
- \\
-\end{array}$ & $\begin{array}{l}\text { Develops themes of Vision Mjölby 2025; identifies strategies to improve urban qualities of Mjölby town centre. } \\
\text { Attempts to balance need for safe street environments and need for mobility for other road-users, including cars. } \\
\text { "Investments in walking and cycling will offer many advantages" in terms of reduced noise and air pollution, fewer } \\
\text { accidents, use of space, etc. and enable "better meetings between people" and new business development (p.15). } \\
\text { Main car thoroughfare to be moved from principal shopping street to a parallel street, although cars and cycles will be } \\
\text { allowed to transit the main street at lower speeds (p.8). Cars are "currently highly-prioritised in the town centre, with } \\
\text { streets and parking spaces for cars taking up too much of the town's space" (p.15). } \\
\text { Despite this, retailers' need for parking spaces for cars (and cycles) is a recurrent theme. Reference to a } 2014 \text { study } \\
\text { indicates practice of intermodal (car to public transport) transit within town; this is used to motivate an } 11 \% \text { reduction in } \\
\text { the number of parking spaces in the town centre, to be offset by increases in parking along the main shopping street and } \\
\text { in new facilities near the town square and train station (p.19). }\end{array}$ \\
\hline $\begin{array}{l}\text { Skänninge } \\
\text { (consultatio } \\
\mathrm{n} \text { document }\end{array}$ & $\begin{array}{l}2014- \\
05-14\end{array}$ & $\begin{array}{l}\text { Town of } \\
\text { Skännin } \\
\text { ge }\end{array}$ & $\begin{array}{l}\text { Urban structure } \\
\text { following } \\
\text { BanaVäg; housing; } \\
\text { premises }\end{array}$ & $\begin{array}{l}- \\
- \\
- \\
-\end{array}$ & $\begin{array}{l}\text { Prioritise sustainable modes of transport as it "shall be easy to live without a car in Skänninge" (p.13). } \\
\text { Increase provision of space for sustainable modes and reduce vehicle speeds ( } \mathrm{p} .19) \text {. } \\
\text { Reduce number of parking spaces in town centre, although "it is important that cars can easily reach the train station and } \\
\text { commuter parking" (pp.75-76). } \\
\text { Expects town to become a hub for regional transfers between rail and bus following opening of new station (p.7). } \\
\text { Possible development of a freight transfer station (p.7). }\end{array}$ \\
\hline
\end{tabular}


Table 3. Overview of key strategic planning documents in Mjölby. 


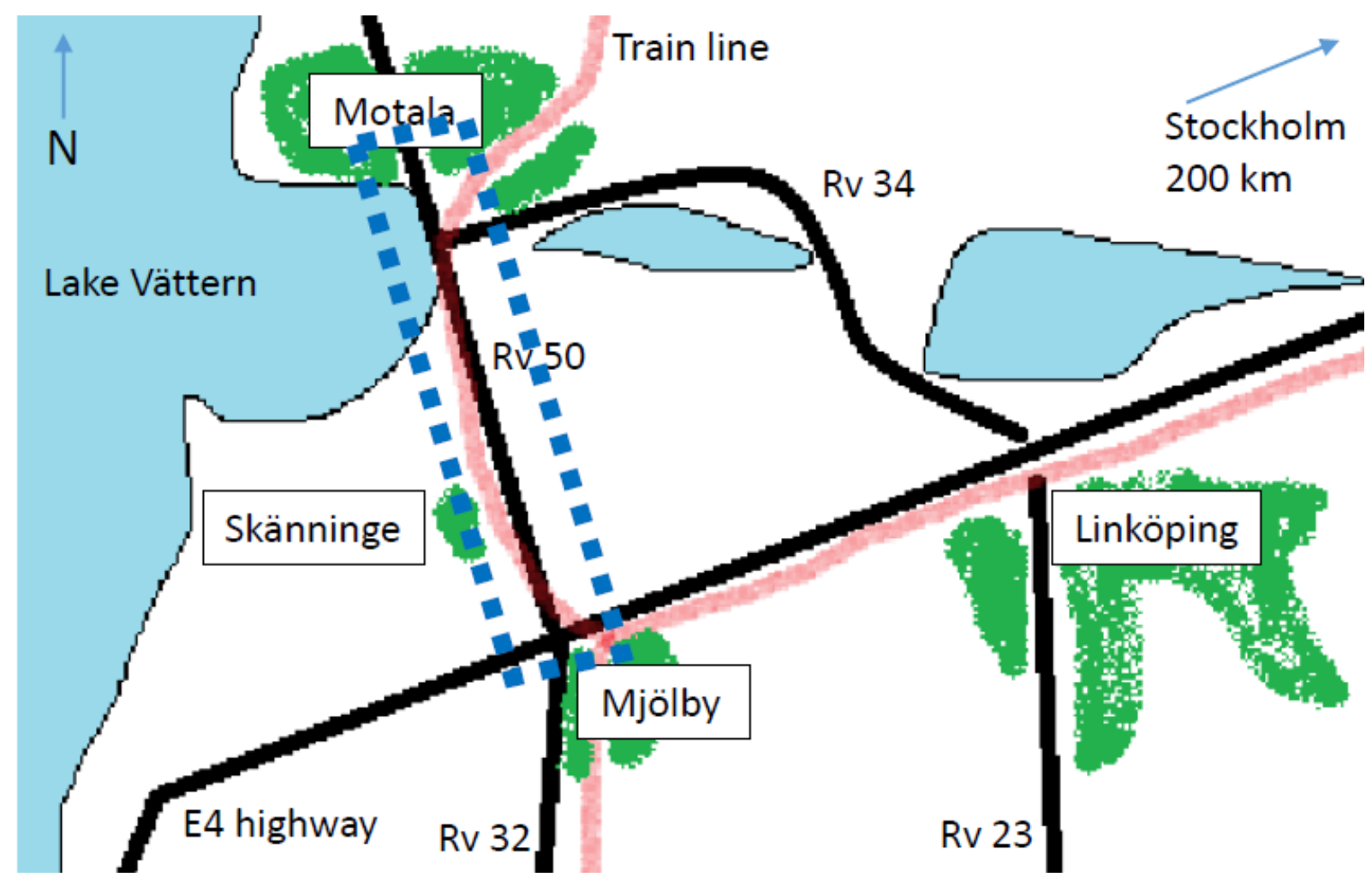

Figure 1. Illustration of the pilot region indicating settlements, geographic features, road and rail infrastructure and the project area (marked with dots). 